\title{
PENINGKATAN KETERAMPILAN BERBICARA MELALUI METODE DISKUSI KELOMPOK MODEL TANAM PAKSA SISWA KELAS X PEMASARAN 1 SMK PGRI 2 KEDIRI
}

\author{
Nur Lailiyah, M. Pd. \\ (PG-PAUD, FKIP, Universitas Nusantara PGRI Kediri, Email : lailiya.online@yahoo.co.id) \\ Widi Wulansari, M. Pd. \\ (PG-PAUD, FKIP, Universitas Nusantara PGRI Kediri, Email : woelans.aries@gmail.com)
}

\begin{abstract}
Abstrak
Penelitian ini bertujuan untuk mengetahui peningkatan keterampilan berbicara melalui metode diskusi model tanam paksa (pengembangan dari model kepala bernomor) kelas X Pemasaran 1 di SMK PGRI 2 Kediri yang meliputi: (1) deskripsi pelibatan seluruh siswa secara aktif dalam kegiatan diskusi kelompok melalui penerapan diskusi model tanam paksa, (2) deskripsi cara mengatasi siswa yang kesulitan dalam mengemukakan pendapat dan memberikan tanggapan terhadap pendapat teman sekelasnya, dan (3) deskripsi peningkatan keterampilan berbicara melalui metode diskusi kelompok model tanam paksa siswa kelas X Pemasaran 1 SMK PGRI 2 Kediri dalam menanggapi pembacaan cerpen tahun pembelajaran 2015/2016. Penelitian ini dilaksanakan di SMK PGRI 2 Kediri melibatkan 28 siswa kelas X Pemasaran 1. Penelitian ini termasuk deskriptif kualitatif. Penelitian ini dilaksanakan dalam 2 siklus dengan tindakan setiap siklus meliputi perencanaan, pelaksanaan tindakan, observasi kegiatan, dan refleksi. Data penelitian diambil melalui lembar observasi aktivitas siswa, tes pencapaian kompetensi belajar siswa, wawancara, dan angket. Hasil penelitian (1) metode diskusi model tanam paksa terbukti dapat melibatkan secara aktif seluruh siswa dalam kegiatan diskusi, (2) metode diskusi model tanam paksa terbukti efektif untuk mengatasi kesulitan siswa dalam mengemukakan pendapat dan memberi tanggapan, (3) metode diskusi model tanam paksa terbukti efektif untuk meningkatkan keterampilan berbicara dalam menanggapi pembacaan cerpen.

Kata kunci: Keterampilan Berbicara, Diskusi, Model Tanam Paksa

Abstract

This study aimed to determine the increase conversational skills through discussion method model of cultivation (development of numbered head model) class X Marketing 1 in SMK PGRI 2 Kediri which includes: (1) a description of the involvement of all students actively in group discussions through the implementation of discussion models cultivation, (2) a description of how to cope with students who have difficulty in expressing opinions and provide feedback to the opinions of their classmates, and (3) a description of improvement of speaking skills through group discussion method model of cultivation class X Marketing 1 SMK PGRI 2 Kediri in response to readings short story in the 2015/2016 academic year. The research was conducted at SMK PGRI 2 Kediri involving 28 students of class X Marketing 1. This research is qualitative descriptive. This study was conducted in two cycles with each cycle includes action planning, action, observation of activities and reflection. The sources of the data were taken through observation sheet student activities, student learning competency achievement tests, interviews, and questionnaires. The results show that (1) the method of discussion model of cultivation proven to actively involve all students in discussions, (2) the method of discussion model of cultivation proved to be effective to address student difficulties in expressing opinions and give feedback, (3) the method of discussion model of cultivation proven effective to improve speaking skills in responding to the reading of short stories.
\end{abstract}

Keywords: Speaking skills, Discussion, Cultivation models

\section{PENDAHULUAN}

\section{A. Latar Belakang}

Pendidikan adalah suatu usaha sadar dan terencana untuk menciptakan suasana belajar agar peserta didik secara aktif mengembangkan potensi dirinya untuk memiliki kekuatan spiritual keagamaan, pengendalian diri, kepribadian, kecerdasan, sikap sosial dan keterampilan yang diperlukan dirinya, masyarakat, bangsa dan negara (Sisdiknas dalam Jumali, dkk, 2004). Proses pendidikan yang diselenggarakan secara formal di sekolah dimulai dari pendidikan formal yang paling dasar (SD) sampai perguruan tinggi (PT) tidak lepas dari kegiatan belajar yang merupakan salah satu kegiatan pokok dengan guru sebagai pemegang peranan utama. Pendidikan sebagai kegiatan pembelajaran telah dilakukan seusia manusia itu sendiri sebagai pelaku pendidikan.

Dalam pengembangan ilmu pengetahuan dan teknologi harus ditunjang oleh kemampuan pemanfaatan, pengembangan, dan penguasaan ilmu terapan dan ilmu pengetahuan dasar secara seimbang. Salah satu usaha untuk meningkatkan penguasaan pengetahuan dasar adalah dengan meningkatkan keterampilan berbahasa. Ruang lingkup pembelajaran bahasa Indonesia di SMK yaitu dari aspek kemampuan berbahasa meliputi 
aspek mendengarkan/menyimak, berbicara, membaca, dan menulis.

Bahasa Indonesia adalah bahasa nasional atau bahasa negara. Standar kompetensi mata pelajaran bahasa Indonsia berorientasi pada hakikat pembelajaran bahasa bahwa belajar bahasa adalah belajar berkomunukasi dan belajar sastra adalah belajar menghargai manusia dan nilai-nilai kemanusiaannya (Depdiknas, 2004). Pembelajaran bahasa Indonesia diarahkan untuk meningkatkan kemampuan siswa untuk berkomunikasi dalam bahasa Indonesia, baik lisan maupun tulis serta menimbulkan penghargaan terhadap hasil cipta manusia.

Secara umum mata pelajaran bahasa Indonesia bertujuan agar peserta didik memiliki kemampuan antara lain: 1) menghargai dan bangga menggunakan bahasa Indonesia sebagai bahasa persatuan dan bahasa negara, 2) memahami bahasa Indonesia dari segi bentuk, makna, dan fungsi, serta menggunakannya dengan tepat dan kreatif untuk berbagai tujuan, keperluan, dan keadaan, 3) menggunakan bahasa Indonesia untuk meningkatkan kemampuan intelektual, serta kematangan emosional dan sosial, 4) berkomunikasi secara efektif dan efisien sesuai denga etika yang berlaku, baik secara lisan maupun tulis, 5) menikmati dan memanfaatkan karya sastra untuk memperluas wawasan, memperhalus budi pekerti, serta meningkatkan pengetahuan dan kemampuan berbahasa, 6) menghargai dan membanggakan sastra Indonesia sebagai khasanah budaya dan intelektual manusia Indonesia (Depdiknas, 2006).

Pendekatan pembelajaran bahasa dan sastra Indonesia adalah pendekatan komunikatif. Dalam pembelajaran pendekatan komunikatif, pembelajaran bahasa bertumpu pada pengembangan kemampuan siswa dalam menggunakan bahasa sebagai alat ungkap pesan atau makna untuk berbagai tujuan berbahasa yang meliputi aspek menyimak, berbicara, membaca, dan menulis. Keterampilan itu merupakan wujud khas perilaku manusia yang bertumpu pada kebermaknaan (Prayitno, 2006) Meskipun pengembangan ilmu pengetahuan dan teknologi selalu diusahakan, namun dalam praktiknya di lapangan masih banyak guru yang menerapkan pembelajaran secara konvensional. Dalam pembelajaran ini, guru hanya menerangkan materi dengan metode ceramah, siswa mendengarkan dan mencatat hal yang dianggap penting. Akibatnya, informasi yang didapat kurang begitu melekat pada diri siswa dan keterampilan berbicara pada siswa menjadi lemah.

Menurut Juhana (2012) terdapat empat faktor yang menyebabkan siswa mengalami kesulitan dalam mengembangkan keterampilan berbicara, yaitu (1) takut salah, artinya siswa takut melakukan kesalahan dalam mengungkapkan pendapat atau gagasan yang dimilikinya, (2) perasaan malu, artinya sifat emosional yang muncul saat siswa diminta untuk berbicara, (3) kecemasan, merupakan perasaan tegang, takut, dan gelisah yang muncul saat siswa diminta mengungkapkan pendapatnya, dan (4) kurang percaya diri, merupakan perasaan yang sering muncul ketika siswa mengungkapkan gagasannya dan ide tersebut kurang dipahami oleh teman-temannya. Gudu (2015) menyatakan bahwa keterampilan berbicara pada siswa tersebut dapat dikembangkan melalui tiga tahapan. Pertama, mengembangkan motivasi, artinya seorang siswa yang baik harus dapat mengembangkan motivasi pada dirinya sendiri untuk dapat mengembangkan keterampilan berbicaranya. Kedua, peran guru, merupakan tugas seorang guru untuk memilih metode yang tepat dan efektif dalam mengembangkan keterampilan berbicara pada siswanya. Berdasarkan pendapat dan penjelasan tersebut, maka perlu strategi belajar 'baru' yang lebih memberdayakan siswa.

Belajar merupakan kegiatan aktif siswa dalam membangun makna dan pemahaman (Suwandi, 2006). Perkembangan ilmu pengetahuan dan teknologi yang menuntut perlunya perbaikan sistem pendidikan nasional dapat dilakukan dengan barbagai upaya, salah satunya adalah penyempurnaan di bidang kurikulum. Kurikulum tingkat satuan pendidikan (KTSP) yang berlaku saat ini merupakan kurikulum operasional yang disusun dan dilaksanakan masing-masing satuan pendidikan (Soehendro, 2006). Pengembangan kurikulum tingkat satuan pendidikan (KTSP) yang beragam mengacu pada standar nasional pendidikan untuk menjamin pencapain tujuan pendidikan nasional. Salah satu strategi belajar yang dapat mengaktifkan siswa dan menjamin tercapainya tujuan pendidikan adalah melalui pendekatan ContextualTeaching and Learning (CTL).

Pendekatan kontekstual (CTL) merupakan konsep belajar yang membantu guru mengaitkan antara materi yang diajarkannya dengan situasi dunia nyata siswa dan mendorong siswa membuat hubungan antara pengetahuan yang dimilikinya dengan penerapannya dalam kehidupan mereka sehari- hari. Pembelajaran ini melibatkan II tujuh komponen utama pembelajaran efektif, yakni konstruktivisme, bertanya, menemukan, masyarakat belajar, pemodelan, dan penilaian yang sebenarnya (Depdiknas, 2003). Salah satu komponen yang digunakan dalam penelitian ini adalah masyarakat belajar atau sering disebut metode diskusi.

Metode diskusi dapat mendorong siswa untuk berdialog dan bertukar pendapat baik dengan guru maupun teman-temannya sehingga mereka dapat berpartisipasi secara optimal tanpa ada atuan-aturan yang terlalu keras namun tetap mengikuti etika yang disepakati bersama. Menurut Suparlan (2007) diskusi dapat dilaksanakan dua bentuk yakni diskusi kelompok kecil dan diskusi kelas. Dalam pembelajaran bahasa Indonesia, diskusi sangat membantu terjadinya komunikasi dua arah. 
Selain untuk meningkatkan keterampilan berbahasa, pembelajaran bahasa Indonesia juga bertujuan untuk meningkatkan kemampuan berpikir dan bernalar untuk memperluas wawasan dan mempertajam kepekaan perasaan siswa. Oleh karena itu, tujuan penerapan metode diskusi lebih ditekankan pada aspek keterampilan berbicara. Dengan demikian, pembelajaran bahasa tidak hanya sekadar mendengarkan guru menerangkan saja, tetapi diperlukan keaktifan siswa di dalam proses belajar mengajar, sehingga terjalin interaksi baik antara siswa dengan siswa maupun dengan guru.

Saat ini metode pembelajaran Bahasa dan Sastra Indonesia yang sudah ada dan banyak dilaksanakan di SMK adalah diskusi kelompok. Dengan menggunakan metode ini, para siswa diharapkan dapat saling belajar bekerja sama dan saling berkomunikasi secara lisan sehingga mampu memecahkan masalah yang didiskusikan.

Berdasarkan pengalaman empirik di lapangan, penggunaan metode diskusi kelompok memiliki keunggulan tersendiri dibandingkan dengan metode ceramah, misalnya, yang selama ini mendominasi kegiatan pembelajaran. Melalui metode ini, kegiatan pembelajaran tidak lagi berpusat pada guru, siswalah yang lebih aktif terlibat dalam kegiatan pembelajaran sedangkan guru hanya memosisikan diri sebagai fasilitator pembelajaran.

Menurut Zaini, dkk. (2004), keunggulan lain yang dimiliki metode diskusi kelompok, di antaranya: (1) membantu siswa belajar berpikir berdasarkan sudut pandang suatu subjek bahasan dengan memberikan kebebasan siswa dalam praktik berpikir, (2) membantu siswa mengevaluasi logika dan bukti-bukti bagi posisi dirinya atau posisi yang lain, (3) memberikan kesempatan kepada siswa untuk memformulasikan penerapan suatu prinsip, (4) membantu siswa menyadari akan suatu problem dan memformulasikannya dengan menggunakan informasi yang diperoleh dari bacaan atau ceramah, (5) menggunakan bahan-bahan dari anggota lain dalam kelompoknya, dan (6) mengembangkan motivasi untuk belajar yang lebih baik.

Faktor-faktor itulah yang melatarbelakangi peneliti untuk membuat penelitian yang berjudul, "Penerapan Metode Diskusi Kelompok Model Tanam-Paksa Sebagai Upaya Meningkatkan Keterampilan BerbicaraSiswa Kelas X Pemasaran 1 SMK PGRI 2 Kediridalam Menanggapi Pembacaan Cerpen Tahun Pembelajaran 2015/2016”.

\section{B. Rumusan Masalah}

Dari latar belakang diatas, maka diperoleh permasalahan sebagai berikut:

1. Bagaimana melibatkan seluruh siswa secara aktif dalam kegiatan diskusi kelompok?

2. Bagaimana mengatasi siswa yang kesulitan dalam mengemukakan pendapat dan memberikan tanggapan terhadap pendapat teman sekelasnya?

3. Bagaimana peningkatan keterampilan berbicara Melalui Metode Diskusi Kelompok Model Tanam Paksa Siswa Kelas X Pemasaran 1 SMK PGRI 2 Kediridalam Menanggapi Pembacaan Cerpen Tahun Pembelajaran 2015/2016?

\section{Kajian Pustaka}

Tanam paksa adalah sebuah model diskusi yang praktis pengembangan dari model kepala bernomor, mudah diaplikasikan, dan juga ekonomis karena hanya menggunakan 2-3 lembar kertas HVS. Model Tanam Paksa yang bertujuan agar siswa terlibat secara aktif dalam kegiatan diskusi kelompok, siswa mampu mengemukakan pendapat dan memberikan tanggapan terhadap pendapat teman sekelasnya.

Model Tanam Paksa merupakan pengembangan teknik pembelajaran Numbered Heads Together atau pembelajaran kepala bernomor ini pertama kali dikembangkan oleh Spencer Kagan (1992). Teknik ini memberikan kesempatan kepada siswa untuk saling membagikan ide-ide dan mempertimbangkan jawaban yang paling tepat.

Menurut Lie (1999) pembelajaran ini mendorong siswa untuk meningkatkan semangat kerja sama mereka. Teknik ini dapat diberikan pada semua mata pelajaran dan pada berbagai tingkatan usia. Numbered HeadsTogether adalah suatu metode belajar dimana setiap siswa diberi nomor kemudian dibuat suatu kelompok kemudian guru memanggil nomor dari siswa untuk melakukan presentasi

Spencer Kagan, 1992 mengembangkan pembelajaran kooperatif teknik Numbered heads together (NHT) atau kepala bernomor. Artinya setiap siswa dalam kelompok diberi kartu nomor

D. Tujuan

Tujuan pembelajaran yang ingin

dicapai melalui penggunaan metode diskusi kelompok model tanam paksa, yaitu

1. Meningkatkan keterampilan berbicara melalui metode diskusi kelompok model tanam paksa.

2. Seluruh siswa aktif dalam kegiatan diskusi kelompok melalui penerapan diskusi model tanam paksa

\section{METODE}

Metode yang digunakan untuk melakukan penelitian ini adalah metode deskripsi kualitatif - Metode deskripsi kualitatif tujuan utamanya menggambarkan atau melukiskan keadaan yang subjektif (Ali, 1987). Penelitian deskriptif ini menggunakan survei yang akan menghasilkan data yang bersifat kualitatif. Data yang bersifat kualitatif digambarkan dengan kata-kata atau kalimat yang dipisahkan menurut kategori. Dan hasil akhir berupa angka-angka atau bilanganbilangan yaitu nilai hasil dari aktivitas siswa. 
Dalam penelitian ini penulis menggunakan metode kualitatif sebab sesuai untuk Penelitian Tindakan Kelas.

Pengertian tindakan kelas dalam bahasa Inggris disebut Class Room Action Research. PTK merupakan jenis penelitian untuk memperbaiki dan meningkatkan profesionalisme guru dalam proses belajar mengajar yang dilakukan di kelas dengan melihat berbagai indikator keberhasilan proses dan hasil pembelajaran yang terjadi pada siswa (Suyatno, 1992).

Setting penelitian ini meliputi: (a) Tempat dan waktu penelitian (b) Subjek penelitian.

1. Tempat dan Waktu Penelitian

Penelitian tindakan kelas in dilaksanakan di SMK PGRI 2 Kediri jalan KH. Abdul Karim nomor 5 tahun pelajaran 2015/2016, sedangkan waktu pelaksanaan dimulai pada tanggal 8 Februari 2015 sampai 29 April 2015. Penentuan waktu berdasarkan kalender pendidikan.

2. Subjek Penelitian

Subjek penelitian yang dimaksud adalah:Siswa kelas X Pemasaran 1 SMK PGRI 2 Kediri tahun pelajaran 2015/2016 dengan tujuan untuk mendapatkan data tentang keterampilan berbicara dan aktivitas siswa dalam belajar mengajar

Pengumpulan data dalam penelitian ini dilakukan melalui teknik:

1. Observasi atau pengamatan

2. Wawancara

3. Angket

a. Observasi atau pengamatan

Untuk melaksanakan observasi selama penelitian berlangsung, pengamat menggunakan instrumen yang berupa lembar observasi. Di sini pengamat akan mengamati aktivitas berpendapat, aktivitas berbicara, dan kelancaran berbicara. Observasi ini direncanakan oleh peneliti berlangsung dua putaran (lembar observasi terlampir). b. Wawancara

Kegiatan wawancara dilakukan setiap berakhirnya putaran. Wawancara dilakukan terhadap beberapa siswa yang aktif dan siswa yang kurang aktif dengan ketentuan sebagai berikut: Pertanyaan tidak berstruktur, dilakukan secara terbuka, Menempatkan orang yang diwawancarai sebagai teman sejawat dan menempatkan orang yang diwawancarai sebagai teman sejawat.

c. Angket

Angket ini dilakukan untuk mengetahui keefektifan penggunaan metode diskusi model kepala bernomor dalam proses pembelajaran mendengarkan cerpen, serta mengetahui tanggapan atau respon siswa terhadap penggunaan metode diskusi di atas.

Mengingat variable yang diteliti terdiri atas variable dengan beberapa indikator didalamnya. Peneliti menganggap metode analisis yang paling tepat adalah metode analisis deskriptif kualitatif, karena dalam penganalisiannya yang terpenting adalah kualitas. Jadi dalam menganalisis data, peneliti akan menguraikan dengan kata-kata.

Adapun tahapan penganalisiannya sebagai berikut:

1. Mengecek dan mencatat data yang diperoleh dari proses pembelajaran, pencatatan dilakukan secara objektif dan netral.

2. Mengelompokan data yang memenuhi kriteria dan dikelompokkan berdasarkan materi, proses, waktu dan hasil.

3. Kemudian penulis menafsirkan data yang ada dalam kalimat pernyataan.

\section{HASIL DAN PEMBAHASAN}

Hasil Penelitian Ulangan Harian Siklus I

Setelah mengikuti proses pembelajaran menanggapi pembacaan cerpen dengan metode diskusi

model kepala bernomor pada siklus I, diperoleh hasil ulangan harian seperti tergambar pada table 2 .

\begin{tabular}{|c|c|c|}
\hline \multicolumn{2}{|c|}{ Tabel 2. Hasil Ulangan Harian Akhir Siklus I } \\
\hline Nilai & Jumlah anak & Persentase \\
\hline $91-95$ & 1 & 3,5 \\
$85-90$ & 2 & 7,1 \\
$80-84$ & 5 & 17,8 \\
$75-79$ & 13 & 46,4 \\
$70-74$ & 2 & 7,1 \\
$60-64$ & 3 & 10,7 \\
$55-59$ & 2 & 7,1 \\
\hline Jumlah & 28 & 100 \\
\hline
\end{tabular}

Keterangan $: \frac{100}{28} \times$ jumlah anak

Pada tabel 2, siswa yang belum menguasai Kompetensi Dasar atau belum tuntas berjumlah 7 anak atau sebanyak $25 \%$. Sedang siswa yang mencapai ketuntasan belajar yaitu memperoleh nilai 75 adalah sebanyak 13 anak atau $46,4 \%$.
Dengan demikian ditinjau dari sudut ketuntasan belajar telah mengalami kenaikan dari $14,2 \%$ menjadi $46,4 \%$.

\section{A. Hasil Siklus I}

Hasil Pengamatan 
Hasil pengamatan yang dilakukan pada siklus I, diperoleh dari lembar pengamatan efektif yang mencakup materi: (1) kehadiran, (2) keberanian bertanya, (2) keberanian menjawab, (3) kerjasama kelompok, (4) partisipasi dalam proses belajar.

Hasil yang cukup menggembirakan bahwa ketika proses pembelajaran menanggapi pembacaan cerpen dengan menggunakan metode diskusi model kepala bernomor berlangsung hampir semua siswa 93\% menampakkan respon yang cukup antusias dengan perasaan senang terpancar dari roman wajah mereka, sehingga mereka dengan kesadaran yang cukup tinggi ikut terlibat aktif melaksanakan kegiatan belajar.

Meskipun memang masih ada tujuh siswa yang mengalami kesulitan dalam mengukut pembelajaran. Diantaranya beberapa anak masih terlihat malu-malu, beberapa anak ada yang tertawa padahal perannya memang tidak sedang tertawa, dan beberapa anak yang tampak ekspresinya masih datar. Dan hanya ada dua siswa yang masih tampak enggan mengikuti kegiatan bermain peran ini, tetapi akan dicoba diungkap alasannya melalui wawancara khusus.

\section{B. Hasil Wawancara}

Wawancara dilakukan bertujuan untuk mengetahui hambatan dan kemudahan yang dialami siswa dalam mengikuti pembelajaran menanggapi pembacaan cerpen melalui metode diskusi kelompok model tanam paksa.

Siswa yang tergolong ke dalam kelompok baik berpendapat bahwa pembelajaran menanggapi pembacaan cerpen melalui metode diskusi kelompok model tanam paksa sangat mengasyikkan, karena mereka merasa menemukan pengalaman baru yang belum pernah dilakukan sebelumnya, yaitu menggunakan metode diskusi model tanam paksa dalam pembelajaran menanggapi pembacaan cerpen.

Siswa yang tergolong dalam kelompok mempunyai antusias tinggi, berpendapat bahwa belajar dengan menggunakan diskusi model tanam paksa ternyata sangat membantu mereka dalam melatih keberanian dan membantu siswa yang kesulitan dalam mengemukakan pendapat. Siswa yang termasuk kelompok kurang berhasil berpendapat bahwa pembelajaran melalui metode diskusi model tanam paksa telah berhasil menggugah semangatnya, tetapi mereka masih mengalami hambatan dalam berbicara dan mengemukakan pendapat karena selama ini atau sebelumnya memang tidak pernah sama sekali mengemukakan pendapat dihadapan teman-teman di kelas.

Ada dua siswa yang termasuk kelompok tidak mengikuti pembelajaran menanggapi pembacaan cerpen dengan menggunakan diskusi model tanam paksa, ternyata dari pengakuannya secara jujur terungkap adanya hambatan psikologis karena mempunyai watak pemalu.

\section{Hasil Penelitian Siklus II}

Hasil Ulangan Harian Siklus II

Kesalahan tindakan yang terjadi pada siklus I diperbaiki pada siklus II yang juga terdiri dari kegiatan perencanaan, tindakan, observasi dan refleksi, yang dirancang berdasarkan kesalahan, kelemahan, dan kekurangan yang sudah terjadi.

Perbaikan yang memperhatikan kesalahan, kelemahan, dan kekurangan pada siklus I, menghasilkan nilai ulangan harian seperti terlihat pada tabel3:

\section{Tabel 3. Hasil Ulangan Harian Siklus II}

\begin{tabular}{|c|c|c|}
\hline Nilai & Jumlah anak & Persentase \\
\hline $95-100$ & 3 & 10,7 \\
$90-94$ & 4 & 14,2 \\
$85-89$ & 7 & 25 \\
$80-84$ & 5 & 17,8 \\
$75-79$ & 5 & 17,8 \\
$70-74$ & 5 & 14,2 \\
\hline Jumlah & 4 & 100 \\
\hline
\end{tabular}

Keterangan $: \underline{100} \times$ jumlah anak

28

Dari tabel 3 tergambar peningkatan ketuntasan belajar dari 46,5\% pada siklus I menjadi $85,7 \%$ pada siklus II, karena sebanyak 24 siswa dari 28 siswa kelas X Pemasaran 1 telah memperoleh nilai ketuntasan dan dianggap telah tuntas dalam menguasai kompetensi dasar materi mendengarkan.

\section{Hasil Siklus II}

\section{Hasil Pengamatan}

Tindakan yang dilakukan pada siklus II hampir sama dengan kegiatan pada siklus I. Dari hasil pengamatan pada siklus II diperoleh data bahwa 24 siswa atau $85,7 \%$ bersikap sangat antusias. Siswa mulai berani dalam mengemukakan pendapat serta dapat menjawab soal yang diberikan.

\section{E. Hasil Wawancara}

Hasil wawancara pada siklus II dari dua siswa berkemampuan tinggi, dan empat siswa berkemampuan sedang menunjukkan adanya peningkatan sikap antusiasme mereka karena merasa lebih rileks dan senang dalam mengikuti proses pembelajaran dengan metode tanam paksa.

Tampak adanya sikap untuk berusaha lebih keras dalam hal berani mengemukakan pendapat dan sikap 
berusaha menjawab pertanyaan yang diberikan meskipun jawaban masih belum tepat. Dan dari situ siswa berkemampuan rendah terungkap bahwa sebetulnya ada keinginan untuk berpendapat dan menjawab seperti teman-teman yang lainnya tetapi secara jujur mengatakan adanya hambatan psikologis karena merasa sangat sulit menghilangkan rasa malunya.

\section{F. Hasil Angket}

Hasil angket yang dijaring melalui angket yang dibagikan kepada seluruh siswa sejumlah 28 anak, sebanyak $85,7 \%$ menyatakan sangat setuju bahwa metode diskusi model tanam paksa sebagai model pembelajaran mendengarkan cerpen adalah sangat menarik, mudah, lebih baik, dan sangat setuju untuk dilanjutkan penggunaannya

Adapun sebanyak $14,5 \%$ siswa menyatakan setuju, dan tidak seorang pun siswa yang menyatakan tidak tahu, tidak setuju, apalagi sangat tidak setuju. Dengan demikian dapat disimpulkan bahwa metode diskusi model tanam paksa sebagai model pembelajaran mendengarkan cerpen mendapat respon sangat positif dari siswa.

\section{PEMBAHASAN}

A. Pelibatan Seluruh Siswa Secara Aktif dalam Kegiatan Diskusi Kelompok.

Diskusi sebagai suatu bentuk pembelajaran umum adalah suatu cara pembelajaran di mana peserta didik (murid, mahasiswa) mendiskusikan (membicarakan, mencari jawaban bersama) dengan cara saling memberikan pendapatnya, kemudian disaring untuk ditemukan kesimpulan.

Metode diskusi kelompok model tanam paksa dikenal sebagai metode yang paling ekonomis dan paling mudah untuk dilaksanakan dalam pembelajaran kooperatif. Metode diskusi kelompok model tanam paksa yang bertujuan agar siswa terlibat secara aktif dalam kegiatan diskusi kelompok, siswa mampu mengemukakan pendapat dan memberikan tanggapan terhadap pendapat teman sekelasnya

Menurut Lie (1999) pembelajaran ini mendorong siswa untuk meningkatkan semangat kerja sama mereka. Teknik ini dapat diberikan pada semua mata pelajaran dan pada berbagai tingkatan usia. Numbered HeadsTogether adalah suatu metode belajar dimana setiap siswa diberi nomor kemudian dibuat suatu kelompok kemudian guru memanggil nomor dari siswa untuk melakukan presentasi.

Tentu saja persyaratan terjadinya pembelajaran dengan diskusi adalah bahwa bahasa benar-benar sudah dikuasai oleh siswa. Guru tidak lagi memberikan perhatian pada bahasa, melainkan keberanian siswa dalam mengungkapkan pendapat ataupun gagasan dalam diskusi. Karena ada sebagian siswa yang tidak mampu untuk berbicara dengan berbagai alasan; takut salah dalam berbahasa, malu ditertawakan, bergantung pada orang lain, dan tidak mengetahui apa yang akan disampaikan.

\section{B. Mengatasi Siswa yang Kesulitan dalam} Mengemukakan Pendapat dan Memberikan Tanggapan Terhadap Pendapat Teman Sekelasnya.

Berdasarkan pengalaman mengajar siswa kelas X Pemasaran 1 tahun pelajaran 2015/2016 tingkat keterampilan dalam berbicara sangat rendah, perlu dirancang kegiatan pembelajaran yang mampu mewujudkan suasana yang aktif, kreatif, efektif, dan menyenangkan.

Sesuai dengan inovasi pembelajaran yang diusulkan, disediakan metode diskusi kelompok model tanam paksa. Metode ini termasuk ke dalam jenis metode diskusi kelompok berbasis pembelajaran kooperatif yang lebih menekankan pengajaran individual meskipun tetap menggunakan pola kooperatif (TeamAssisted Individualization). Dalam praktiknya, metode diskusi kelompok model tanam paksa didukung oleh penggunaan alat bantu berupa nomor kepala yang terbuat dari kertas HVS berukuran $5 \mathrm{~cm}$ x $5 \mathrm{~cm}$. Penggunaan kertas HVS ini dimaksudkan agar mudah digulung sehingga siswa tidak dapat melihat nomor kepala yang akan dipilih.

Kompetensi yang harus dikuasai oleh siswa lebih ditekankan pada kompetensi individual meskipun dilakukan dalam bentuk diskusi kelompok. Penggunaan metode tanam paksa dimaksudkan sebagai upaya untuk membangkitkan motivasi/siswa secara individual dalam mengemukakan pendapat atau tanggapan secara lisan. Dengan menggunakan metode ini, siswa tidak bisa lagi bergantung kepada sesama anggota. Setiap anggota memiliki rasa tanggung jawab yang tinggi terhadap setiap permasalahan yang dibahas dalam forum diskusi. Dengan cara demikian, setiap anggota akan selalu siap jika sewaktuwaktu ditunjuk oleh guru berdasarkan nomor kepala yang dimilikinya.

\section{Meningkatkan Keterampilan Berbicara Melalui Diskusi Kelompok Model Tanam Paksa.}

Inovasi metode diskusi kelompok yang diharapkan dapat menciptakan suasana pembelajaran yang aktif, kreatif, efektif, dan menyenangkan untuk mengatasi permasalahan tersebut adalah metode diskusi kelompok model Tanam Paksa. Landasan filosofis penggunaan metode diskusi kelompok model Tanam Paksa dalam kegiatan pembelajaran adalah metode konstruktivistik. Asumsi sentral metode ini adalah bahwa belajar itu menemukan. Meskipun guru menyampaikan sesuatu kepada siswa, mereka melakukan proses mental atau kerja otak atas informasi yang diterima sehingga informasi tersebut masuk ke dalam pemahaman mereka. Konstruktivistik dimulai dari masalah untuk selanjutnya berdasarkan bantuan guru, 
siswa dapat menyelesaikan dan menemukan langkah-langkah pemecahan masalah tersebut.

Metode konstruktivistik didasarkan pada teori belajar kognitif yang menekankan pada pembelajaran kooperatif, pembelajaran generatif, strategi bertanya, inkuiri, atau menemukan dan keterampilan metakognitif lainnya (belajar bagaimana seharusnya belajar). Pembelajaran yang bernaung dalam metode konstruktivistik adalah kooperatif. Pembelajaran kooperatif muncul dari konsep bahwa siswa akan mudah menemukan dan memahami konsep yang sulit jika mereka saling berdiskusi dengan temannya. Siswa secara rutin bekerja dalam kelompok untuk saling membantu memecahkan masalah-masalah yang kompleks (Depdiknas, 2005).

Hal senada juga dikemukakan oleh Zahorik (Depdiknas, 2004) yang menyatakan bahwa pengetahuan dibangun oleh manusia sedikit demi sedikit, yang hasilnya diperluas melalui konteks yang terbatas (sempit) dan tidak sekonyong-konyong. Pengetahuan bukanlah seperangkat fakta-fakta, konsep, atau kaidah yang siap untuk diambil dan diingat. Manusia harus mengkonstruksi pengetahuan itu dan memberi makna melalui pengalaman nyata. Siswa perlu dibiasakan untuk memecahkan masalah, menemukan sesuatu yang berguna bagi dirinya, dan bergelut dengan ide-ide. Esensi dari teori konstruktivistik adalah ide bahwa siswa harus menemukan dan mentransformasikan suatu informasi kompleks ke situasi lain, dan apabila dikehendaki, informasi itu menjadi milik mereka sendiri.

Ada beberapa model diskusi kelompok berbasis pembelajaran kooperatif (Depdiknas, 2005) antara lain sebagai berikut.

1. Student Teams-Achievement Divisions (STAD) yang menggunakan langkah pembelajaran di kelas dengan menempatkan siswa ke dalam tim campuran berdasarkan prestasi, jenis kelamin, dan suku.

2. Team-Assisted Individualization (TAI) yang lebih menekankan pengajaran individual meskipun tetap menggunakan pola kooperatif.

3. Cooperative Integrated Reading and Composition (CIRC) yang digunakan untuk pembelajaran membaca dan menulis tingkat tinggi.

4. Jigsaw yang mengelompokkan siswa ke dalam tim beranggotakan enam orang yang memelajari materi akademik yang telah dibagi-bagi menjadi beberapa subbab.

5. Learning together (belajar bersama) yang melibatkan siswa untuk bekerja dalam kelompok beranggotakan empat atau lima siswa heterogen untuk menangani tugas tertentu.

6. Group Investigation (penelitian kelompok) berupa pembelajaran kooperatif yang bercirikan penemuan.
Berdasarkan permasalahan yang ada dalam pembelajaran Bahasa dan Sastra Indonesia di SMK, khususnya dalam pembelajaran kemampuan menanggapi pembacaan cerpen, jenis metode diskusi kelompok yang diduga lebih tepat untuk memecahkan masalah tersebut adalah Team-Assisted Individualization (TAI). Meskipun tetap menggunakan pola kooperatif, metode ini lebih menekankan pengajaran individual. Metode ini diimplementasikan dengan menggunakan model Tanam Paksa untuk memberikan kesempatan dan keleluasaan kepada siswa secara individual untuk menumbuhkembangkan potensi dirinya.

\section{PENUTUP}

\section{Simpulan}

Berdasarkan hasil analisis dan pembahasan di atas dapat disimpulkan sebagai berikut:

1. Melalui metode diskusi model tanam paksa ternyata terbukti dapat melibatkan siswa secara aktif dalam berdiskusi dan dapat menciptakan suasana pembelajaran yang menyenangkan serta menarik minat para siswa kelas X Pemasaran 1 SMK PGRI 2 Kediri.

2. Metode diskusi model tanam paksaefektif untuk mengatasi siswa yang kesulitan untuk mengemukakan pendapat dan memberi tanggapan terhadap pendapat teman sekelasnya.

3. Penggunaan metode diskusi model tanam paksa ini ternyata terbukti efektif untuk meningkatkan kemampuan siswa dalam menanggapi pembacaan cerpen. Aspek kelancaran berbicara, kejelasan vokal, ketepatan intonasi, ketepatan pilihan kata, ketepatan mengungkapkan tokoh-tokoh cerita, kemampuan menjelaskan karakteristik tokoh, kemampuan menjelaskan latar cerita, dan kemampuan menulis kembali cerpen yang didengar, dapat diterapkan dengan baik oleh siswa ketika menanggapi pembacaan cerpen.

4. Cukup efektif untuk menumbuhkembangkan kedisplinan, minat, kerja sama, keaktifan, dan tanggung jawab siswa karena metode diskusi kelompok model tanam paksa menekankan kemampuan siswa secara individual meskipun dilaksanakan secara berkelompok.

5. Cukup efektif untuk menumbuhkan budaya kompetetif di kalangan siswa karena secara kejiwaan siswa memiliki motivasi yang tinggi untuk tampil sebaik-baiknya secara individual dan memiliki keterlibatan emosional untuk menjaga solidaritas kelompok ketika menyampaikan hasil diskusi.

Kegiatan pembelajaran benar-benar berpusat pada siswa sehingga dapat menemukan jawaban sendiri (inkuiri) terhadap permasalahan yang didiskusikan. Guru hanya sebatas menjadi fasilitator yang membantu siswa dalam menumbuhkembangkan potensi dirinya. 
Peningkatan Keterampilan Berbicara Melalui Metode Diskusi Kelompok Model Tanam Paksa Siswa Kelas X Pemasaran 1 SMK PGRI 2 Kediri

Nur Lailiyah, Widi Wulansari

\section{DAFTAR PUSTAKA}

Bahasa Indonesia SMK/MAK Setara Tingkat 170 Tingkat Madya Kelas XII Depdiknas, 2003. Kurikulum 2004. Standar Kompetensi Mata Pelajaran Bahasa dan sastra Indonesia. Jakarta: Depdiknas.

Ali, Mohammad. 1987. Penelitian Kependidikan Prosedur dan Strategi. Bandung: Angkasa.

Depdiknas. 2004. Perpustakaan Perguruan

Tinggi: Buku Pedoman, edisi ketiga. Jakarta: Depdiknas.

Depdiknas. 2005. Panduan Pengembangan Model Pembelajaran Berbasis Kompetensi. Jakarta: Direktorat PPTK dan KPT Dirjen Dikti.

Depdiknas. 2006. Kurikulum Tingkat Satuan Pendidikan (KTSP). Jakarta: Depdiknas.

Gudu, Benter Oseno. 2015. Teaching Speaking Skills in English Language using Classroom Activities in Secondary School Level in Eldoret Municipality, Kenya. Journal of Education and Practice. No. 35 Vol. 6, 55 63

Juhana. 2012. Psychological Factors That Hinder Students from Speaking in English Class (A Case Study in a Senior High School in South Tangerang, Banten, Indonesia). Journal of Education and Practice. No. 12 Vol. 3, $100-110$

Jumali, dkk. 2004. Landasan Pendidikan. Surakarta: Muhammadiyah University Press

Anita, Lie. 1999. Cooperative Learning Mempraktikkan Cooperative Learning di Ruang-Ruang Kelas, Jakarta: PT. Grasindo Widia Sarana Indonesia

Kagan, Spencer. 1992. Cooperative Learning. San Juan Capistrano: Kagan Coopertive Learning.

Suparlan. 2007. Menjadi Guru Efektif, Jakarta: Hikayat Publishing

Endraswara, Suwandi. 2006. Metodologi Penelitian Sastra, Epistemologi, Model, Teori, dan Aplikasi. Jogyakarta: Pustaka Widyatama

Zaini, Hisyam, dkk. 2004. Strategi Pembelajaran Aktif. Yogyakarta: CSTD. 